\title{
BEYOND CAPM: AN INNOVATIVE FACTOR MODEL TO OPTIMIZE THE RISK AND RETURN TRADE-OFF
}

\author{
Mauro ANDRIOTTO ${ }^{1}$, Emanuele TETI ${ }^{2}$ \\ CReSV Research Centre and Department of Finance, Bocconi University, \\ Via Roentgen 1, 20136 Milan, Italy \\ E-mails: ${ }^{1}$ mauro.andriotto@unibocconi.it; \\ 2emanuele.teti@unibocconi.it (corresponding author)
}

Received 17 July 2012; accepted 18 January 2013

\begin{abstract}
Different models have tried to improve the Capital Asset Pricing Model findings, on the basis that different factors can affect asset return. This paper examines a series of explanatory factors, broader than those explained by traditional theory, to see whether they are able to more accurately explain the returns. Should the previous point be confirmed, we must consider that the risk of an asset depends on multiple factors, rather than the few that are usually identified in the literature. Even though more than 300,000 factors are examined in this paper, the results show that in recent years just 87 factors are able to fully explain the returns of 4,500 companies in the 15 European countries examined. Our analysis also shows that business and macroeconomic, rather than financial factors, are those that heavily bear on asset returns; and that factors that affect asset return, either only positively or only negatively, do not exist. However, the same factor can affect some companies positively and others negatively. Thus, since not all firms are always sensitive to the same factors, there is the possibility to further decrease risk in proportion to return, through a factor-based risk optimisation process.
\end{abstract}

Keywords: equity return, risk and return trade-off, capital asset pricing model, macroeconomic factors, equity indices, commodities, factor analysis, arbitrage pricing theory.

JEL Classification: G10, G11, M2.

\section{Introduction}

The Capital Asset Pricing Model (CAPM) and its improved versions still represent the reference models to investigate expected equity return and the relationship between risk and return (Sharpe 1964; Fama, French 2004). In the last forty years, researchers have debated the model's validity. Assertions included in the CAPM theory have been debated and developed to a different extent by prominent scholars, who have added significant contributions to knowledge. Nonetheless, researchers agree that they do not fully recognise all the key risk factors that analysts should consider when assessing equity risk. Moreover, important business and economic factors, different from systematic market risk, surely impact the risk and return profile of assets, and should be identified. In addition, it should be assumed that diversification cannot always be 
fully achieved, and that other diversifiable factors impact the markets and which traditional models cannot incorporate. Clearly, for some businesses, it is fairly easy to determine the primary factors that are responsible for a certain return; in other cases, a more formal and empirical research is required to find an adequate explanation. We believe that each company, industry or market is indisputably tied to specific factors, whose weight and movements vary over time, and can be examined to explain return trends. The main tenet of this paper is to demonstrate the existence of business and macroeconomic factors that are responsible for asset return. We first identify a series of factors that are able to explain the returns. We then measure how these factors affect the risk and return trade-off of assets. Since not all companies are sensitive to the same factors, investors have the opportunity to further decrease risk in proportion to return, through a factor-based risk optimisation process. The remainder of the paper is structured as follows. In the Section 1 we introduce the hypotheses and the research questions. Section 2 reviews the main literature contributions. Section 3 introduces the data, identifying the sample of companies and the set of factors examined. Section 4 explains the methodology used to build the new model. Section 5 shows the results of the analyses and discusses the main implications.

\section{Assumptions and research hypotheses}

Different papers have recently tried to justify the CAPM using simplistic assumptions. Levy (2010) states that some unsatisfactory results obtained through the CAPM could be solved by establishing risk factors (beta) ex ante, rather than ex post, in an empirical manner. Li and Yin (2011) recognise that the CAPM would not be able to accommodate information asymmetry and belief-updating that distinguishes a continuously changing market. The authors try to resolve this problem, but their improvement is still grounded on a single-factor model, such as the CAPM.

Our paper is based on empirical work that considers some of the assumptions already considered by the CAPM and subsequent works, and interjects some new hypotheses into the model. Four basic assumptions, upon which CAPM is grounded (Sharpe 1964; Jensen 1972; Levy et al. 2012), are considered: (1) all investors seek to maximise the expected utility of their terminal wealth by choosing among alternative assets on the basis of the risk and return trade-off; (2) all assets are perfectly divisible and perfectly liquid; (3) there are no taxes and no transaction costs; and (4) all investors are price takers, that is, they assume that their own buying and selling activity will not affect stock prices.

Contrary to the CAPM, this work has five hypotheses that the original study does not consider.

HP 1: Risk and return are explained by different factors. Some of these factors can be regularly monitored (e.g., Gross Domestic Product, GDP), while others cannot be efficiently measured (e.g., political risk). A first peculiarity based on nature can distinguish between different typologies of risk: geo-political, macroeconomic, market and financial, business and corporate governance, industrial and sectoral, 
asset-specific (e.g., financial leverage ratios of the companies). Most factors can be identified based on their strength and level of influence: world, economic area (e.g., Europe or U.S.), country, industry, and/or single company. It would be interesting to observe whether basic CAPM assumptions, which base returns on equity betas, can be sustained, by supporting that non-diversifiable factors are sufficient to express the risk and return trade of assets, or whether factors that cannot be easily incorporated in equity beta are key. Furthermore, we also assume that there are no riskless arbitrage profit opportunities. In other words, if two or more assets depend on the same factors, the returns will depend solely on the factor-specific sensitivity of the assets.

HP 2: Not all investors are perfectly rational and have the same expectations. Unlike the CAPM assumptions, this hypothesis suggests that not all factors are diversified (i.e., diversification is not always fully achieved), and that investors allocate assets to a portfolio differently. Should this hypothesis be true and, thus, not all factors should be diversified as the CAPM indicates, we should expect that asset returns will not always be explained by a unique factor only or the same group of factors, but by different types of factors.

HP 3: Factors can have a positive or negative effect on returns. Each factor in our model can affect: a) positively all companies, b) negatively all companies, c) positively some companies, d) negatively some other companies. The presence of factors with a negative effect can explain negative returns. However, the hypothesis suggests that the different factors influencing an asset should have a positive expected value, in order to persuade investors to hold it in their portfolios, at least over the long term.

HP 4: Not all factors have equal importance. We assume that the impact of factors on returns changes over time depending on fluctuations in the economic, financial and social environments. That is, over time, there are various factors that impact returns. We have called this measure the "Relative Importance Index", defined as:

$$
R I I_{p}=\frac{\beta_{p} * \frac{1}{T} \sum_{t=1}^{T} f_{t, p}}{\sigma_{G}},
$$

where $\beta_{p}$ is the sensitivity of the portfolio's return to factor $p ; f_{t, p}$ is the change of factor $i$ between two periods; and $\sigma_{G}$ is the standard deviation of the portfolio $G$ (see Appendix for the extended formula).

HP 5: The impact of a factor on returns changes over time. For instance, the impact of oil price varies by day depending on the economic climate and the management of energy sources. This also means that the number of factors used to explain a return increases, or at least changes, with the extension of the time horizon. 


\section{Background literature}

Different studies have discussed the assumptions behind the CAPM. Some models use adjusted criteria to rebalance the unexpected risk-free changes, while others assume that investor consumption preferences are time-independent and generate multi-period betas (Bergman 1985). In this respect, even though Markowitz (Markowitz 2005: 17) recognises that the CAPM is an "elegant theory" and "comes to dramatic conclusions about practical matters", he also asserts that the premises are not realistic and if they are changed then the market portfolio is no longer efficient. Levy (2010:63) claims that the "inconclusive" empirical results achieved by the CAPM could be settled by allowing ex ante beta to be included in the formula. Magni (2009) debates the validity of the CAPM by discussing the link between "two of the most important ideas in finance" the net present value (NPV) and the CAPM. The author indicates that the reliability of the NPV is limited under uncertainty, just because the "CAPM budgeting decision-making based on disequilibrium NPV is deductively inferred by CAPM" (Magni 2009: 549). Li and Yin (2011) recognise that the risk and return of assets can be better explained by an "information-adjusted beta" rather than the market beta, as identified by the classical CAPM. The first author to identify the need to consider the impact of a series of factors on risk, also of a business nature, is Ross (1976). He introduced the Arbitrage Pricing Theory (APT); however, the APT does not identify specific factors or their weight, as opposed to the series of factors identified in our paper. Rogov (2006) suggests that even naturally-occurring factors like solar and geothermic activity can impact operational, credit and market risk. Roll (1977) asserts that CAPM limitations can be due to the fact that most indexes include only common stocks, while a market portfolio should incorporate all types of investments: stocks, bonds, commodities and real estate. Following the APT path, Fama and French (1992) explain that the risk premium depends on market risk as explained by the CAPM, as well as company size and the book-to-market ratio. Researchers recognise that size, age, liquidity and long-term debt impact company profitability (Nunes et al. 2012), as well as corporate reputation (Teti et al. 2012). The variability that can be generated by the momentum anomaly was analysed by Carhart (1997) and included in the four-factor model. Elton et al. (1994) state that asset returns can be better explained by identifying a series of factors rather market risk only; however, since the factors are not clarified, the authors recognise the difficulties in applying multi-factors models. Bistrova et al. (2011) suggest that stock returns are inversely related to the level of company debt, while Hsinga and Hsieh (2012) emphasise the weight of macroeconomic factors on asset returns. In addition, Lee et al. (2009) recognise the limitation of static CAPM decisions, as they are highly affected by the supply of risky securities. Finally, the recent financial crisis has brought up questions as to the practical relevance of the CAPM, as the slope of the security market line could be negative (Siegel 2010). This contribution fully agrees with our assumption that the market, as every other asset, depends on a set of factors, some with a positive influence and others with a negative influence. In this paper, we recognise the benefits of a multi-factor model when assessing asset returns, yet we also identify and test more than 300,000 different factors and rank them according to their ability to impact asset returns. 


\section{Data}

\subsection{The sample of companies}

We analysed 9,260 companies for the 1950 to 2007 period. More recent data were not available for all the 311,932 factors investigated. Furthermore, the objective here is the creation of a model that is able to satisfactorily meet the objectives of the paper. Data referring to time series were drawn from DataStream. As for the geographical areas of the examined companies, data for fifteen of the most important European countries were examined: Austria, Belgium, Denmark, Finland, France, Germany, Greece, England, Ireland, Italy, Netherlands, Norway, Portugal, Spain and Sweden, extensively covering forty of the major industries. The European investigation was to extend current knowledge beyond the U.S. context, where most studies on the CAPM and associated key theories (Fama, MacBeth 1973; Roll, Ross 1980; Fama, French 1992; Carhart 1997), as well as recent contributions (Lee et al. 2009; Kostakis 2009; Levy 2010) have been developed. Furthermore, the idea was to analyse an environment that, despite some political and economic differences, is a sufficiently homogenous area, with common commodity, index and macroeconomic indexes.

\subsection{The sample of factors}

The 311,932 factors we examined are from DataStream and analysed on a world-wide scale over the period 1950-2007. The 311,932 factors can be broken down into four main groupings:

1. About 270,000 business and macroeconomic variables, covering factors such as a country's GDP, labour costs, unemployment rates, demographic estimates, work productivity, interest rates, and many others. These were measured on an annual, four-monthly, monthly, weekly and daily basis.

2. Approximately 7,000 commodity prices, such as prices of metals, vegetables, chemicals, oil, fibres, and many others were examined. These were measured on a daily basis.

3. Approximately 31,000 equity indices that, in turn, can be gathered into three subgroups: global market indices; industry indices; industry, market and asset indices built by the key investment banks. These indices were measured on a daily basis.

4. Market indices that we constructed by weighting the company returns were included in the sample by their market capitalisation.

\section{Methodology}

Different methodologies have been used in the literature to test the CAPM and related theories. Most of them debate the single-factor model as the original CAPM theory, proposing interesting methodology adjustments. Levy (2010) argues the validity of the original CAPM results, based on ex post beta determined empirically, by indicating that considerable improvement can made by constructing ex ante beta. This adjustment recalls a previous contribution from the author in which he uses ex post parameters to show that the CAPM findings are questionable, while they are not when ex ante beta are 
introduced into the formula (Levy 1983). Li and Yin (2011) adjust the CAPM singlefactor methodology by estimating the excess return of risky assets using informationadjusted beta, rather than market beta. Most of the multi-factor CAPM models are concordant with the methodology we use. Jensen (1972) introduces into the regression an intercept, $\alpha_{\text {Jensen }}$, showing whether or not the investor can add value based on the specific risk he assumes. Also, Fama and French (1993) use the regression model to link asset return to the size (Small Minus Big, SMB) and value (High, Minus Low, HML) factors. Carhart (1997) adds momentum (Momentum, MOM) as a fourth factor in the regression. More recently, Kostakis (2009) used a regression model to build a zero-cost negative coskewness portfolio, and regressed the market model for each individual stock he examined. Our work based on multiple-factor analysis uses a consistent methodology as examined in the papers investigated. Two main methodological procedures have been followed: analysis of redundant variables and factor analysis.

\subsection{Analysis of redundant variables}

The gigantic amount of factors analysed could bring about redundant variable issues. In order to control for this possibility, an autocorrelation matrix was created with the 311,932 factors to exclude all of those that generate Pearson correlation indices higher, in absolute value, than 0.5 , that is: $\left|\rho_{k, i}\right|>0.5$, with $k=1,2,3, \ldots, n ; i=1,2,3, \ldots, n$; and where $k$ and $i$ represent, respectively, the $k_{t h}$ and $i_{t h}$ factor, and $\rho_{k, i}=\frac{\operatorname{COV}(k, i)}{\sigma_{k} \sigma_{i}}$. This step helped to reduce potential multicollinearity problems. The measurement of the factors was possible at different frequencies, except for macroeconomic data that were available at specific deadlines (see Table 1).

Table 1. Factors analyzed by group and available data frequencies

\begin{tabular}{lcc}
\hline \multicolumn{1}{c}{ Group } & Number of factors & Available frequencies \\
\hline Commodities & 6,325 & Annual, monthly, daily \\
\hline Equity indices & 25,871 & Daily \\
\hline Business and macroeconomic & 70,153 & Annual \\
\hline Business and macroeconomic & 96,762 & Quarterly \\
\hline Business and macroeconomic & 172,570 & Monthly \\
\hline Business and macroeconomic & 254 & Weekly ${ }^{1}$ \\
\hline Business and macroeconomic & 891 & Daily \\
\hline
\end{tabular}

Note: Different macroeconomic data are available at different frequencies. For example, GDP is available at annual frequency, while inflation rate as monthly frequency.

${ }^{1}$ Measured every five days.

To solve the problem of different available frequencies, we aggregated the groups of factors based on their frequency, choosing the lowest frequency available (e.g., the daily frequency when available). This brought about a correlation matrix, from which 
some factors were discarded, and then the lowest frequency was converted into a higher frequency (e.g., the daily frequency was converted into a weekly frequency). The procedure was repeated until the maximum frequency (annual frequency) was reached. Opinions differ in the literature on what level of correlation should be used to identify redundant variables, but in practice the range: $0.5<|\rho|<0.9$ is "commonly" used (Cequity 2009). Thus, we have chosen a value of $|\rho|>0.5$.

"Factor Relevance" (FR) for every pair of factors considered was used for the discarding procedure. We kept factors with the highest FR as they are able to affect all the others. FR is calculated as follows:

$$
F R_{k}=\sum_{i=1}^{n} \rho_{k, i}
$$

and

$$
F R_{i}=\sum_{k=1}^{n} \rho_{k, i},
$$

where $F R_{k}$ is the factor relevance of the generic factor $k$ and $F R_{i}$ is the factor relevance of the generic factor $i$. Note, that if $i=k$, then $F R_{k}=F R_{i}$.

Finally, with MATLAB, a parallel code was developed in a computer cluster, generating about 50 billion correlation calculations, so the initial 311,932 factors were reduced to 407 .

\subsection{Factor analysis}

A regression analysis was conducted by following four main steps: definition of a regression model (5.2.1.), time series stepwise regressions (5.2.2.), portfolio building on the basis of common factors (5.2.3.), and cross section regressions (5.2.4.).

\subsubsection{Definition of a regression model}

The same model suggested by Fama and French (1992) is employed. The model can be formalised according to the following formula, expressing the return of the $G_{t h}$ asset at time $t$ :

$$
r_{G}=\alpha+\sum_{i=1}^{n} \beta_{i} f_{i}+\varepsilon_{i},
$$

where, in order to test the possible strength variation of a factor over time, we considered eight periods: seven periods of five years from 1965 to 2000 (A, B, C, D, E, F, and $\mathrm{G}$ ) and one longer period of eight years, from 2000 to $2007(\mathrm{H})$. The time horizon also makes it possible to remove the delisted companies from one period to another. As we believe that the strength of a factor can change over time, the number of factors cannot be defined in advance, but should be selected according to the investor's time horizon. Furthermore, the number of factors considered should also be related to the level of accuracy of the analysis, measured by $R^{2}$. To test the hypothesis regarding the relation between the number of factors required to explain the returns, and the extension of the time horizon considered, we selected the factors by using an algorithm that sought the maximisation of the model's $R^{2}$ and imposing that $n<\omega$ (where $\omega$ is number of observations). 


\subsubsection{Time series stepwise regressions}

In order to manage 407 variables, we used a stepwise procedure with the following selection criteria: a factor is added if its $p$-value is lower than .01, and is removed if its $p$-value is higher than .005 . The procedure concludes when there are no more variables that can be added or removed. The validity of the model is evaluated by calculating the adjusted $R^{2}$ :

$$
\bar{R}^{2}=1-\frac{S S_{\text {err }}}{S S_{\text {tot }}} \frac{d f_{t}}{d f_{e}},
$$

where $S S_{\text {err }}=\sum_{i}\left(y_{i}-f_{i}\right)^{2}$ is the residual sum of squares, $y_{i}$ are observed values and $f_{i}$ are predicted values; $S S_{\text {tot }}=\sum_{i}\left(y_{i}-\bar{y}\right)^{2}$ is total sum of squares; $d f_{t}$ are degrees of freedom $(n-1)$ of the population variance estimate of the dependent variable; and $d f_{e}$ are the degrees of freedom $(\omega-n-1)$, with $\omega$ as sample size and $n$ as number of regressors.

\subsubsection{Portfolio building on the basis of common factors}

A series of $n$ portfolios, each one made up of the assets sharing the same factors, was built.

\subsubsection{Cross section regressions}

The validity of the betas was tested by performing a series of cross-section regressions on the $p$ portfolios as built at point 5.2.3., according to the following equation:

$$
\bar{r}_{p}=\grave{\gamma}_{0}+\sum_{k=1}^{n} \beta_{p, k} \hat{\gamma}_{p, k}+\varepsilon_{p} .
$$

Should the results be confirmed, then we would theoretically obtain that $\forall k: \widehat{\gamma}_{k, p}=f_{k, p}$.

\section{Results and discussion}

We examined seven periods of five years (A, B, C, D, E, F, and G) and one period of eight years, with $(\mathrm{H})$ describing the explanatory regressors identified at each period. The relative predictive power of the model is shown in Table 2.

Table 2 shows the significant results. First, the regression algorithm helps us to identify the factors that explain the asset returns. The most relevant results concern $\bar{R}^{2}$ results, which in most cases are close to 1 , indicating a high level of accuracy. This process makes further cross-sectional analysis and the portfolio-building step useless, since the steadiness of beta over the periods examined is fully confirmed.

At first, the possible occurrence of data-mining problems was one of the most potential concerns. An analysis conducted on over 300,000 factors and almost 8,000 companies in fifteen countries for a time-length of more than 50 years, represents the typical scenario for this kind of problem. However, after considering the average results of $p$-values and observing the factors selected, we concluded that if some data-mining problems arose (a possibility to consider with almost 10,000 regressions), they would be considered as suf- 
Table 2. Results of multiple regressions. Explanatory regressors per sub-periods analyzed

\begin{tabular}{|c|c|c|c|c|c|c|c|c|}
\hline Regressions - resumptive table & A & B & $\mathrm{C}$ & $\mathrm{D}$ & $\mathrm{E}$ & F & G & $\mathrm{H}$ \\
\hline No. of companies & 154 & 291 & 569 & 428 & 805 & 1482 & 1648 & 4540 \\
\hline Year (start) & 1965 & 1970 & 1975 & 1980 & 1985 & 1990 & 1995 & 2000 \\
\hline Year (end) & 1970 & 1975 & 1980 & 1985 & 1990 & 1995 & 2000 & 2007 \\
\hline Length (years) & 5 & 5 & 5 & 5 & 5 & 5 & 5 & 8 \\
\hline $\begin{array}{l}\text { Average no. of regressors } \\
\text { used per company }\end{array}$ & 2.29 & 1.97 & 2.12 & 1.64 & 2.25 & 2.17 & 1.75 & 5.85 \\
\hline Mean R-squared adjusted & 0.97 & 0.95 & 0.96 & 0.92 & 0.96 & 0.96 & 0.93 & 0.99 \\
\hline $\begin{array}{l}\text { Mean correlation value } \\
\text { between factors }\end{array}$ & 0.43 & 0.33 & 0.37 & 0.23 & 0.42 & 0.38 & 0.25 & 0.43 \\
\hline Mean P-Value regressors & 0.0002 & 0.0001 & 0.0001 & 0.0001 & 0.0001 & 0.0001 & 0.0001 & 0.0002 \\
\hline Intercept & A & B & $\mathrm{C}$ & $\mathrm{D}$ & $\mathrm{E}$ & $\mathrm{F}$ & G & $\mathrm{H}$ \\
\hline Intercept (mean) & -0.015 & 0.122 & 0.047 & 0.165 & 0.176 & -0.002 & 0.030 & -0.069 \\
\hline$\left(1-\sum_{k=1}^{n} \beta_{i, k}\right) r_{f}$ & 0.087 & 0.312 & -1.055 & 0.205 & 0.222 & 0.008 & 0.034 & -0.181 \\
\hline Intercept (median) & -0.015 & 0.036 & 0.014 & 0.172 & 0.139 & 0.000 & 0.057 & -0.011 \\
\hline Intercept (standard deviation) & 0.052 & 0.216 & 0.594 & 0.457 & 0.431 & 0.013 & 1.090 & 1.345 \\
\hline Factors & A & B & $\mathrm{C}$ & $\mathrm{D}$ & $\mathrm{E}$ & $\mathrm{F}$ & G & $\mathrm{H}$ \\
\hline Macroeconomic (\%) & 100 & 95 & 88 & 88 & 94 & 91 & 77 & 95 \\
\hline Equity indices (\%) & 0 & 5 & 12 & 12 & 6 & 9 & 23 & 5 \\
\hline Commodities (\%) & 0 & 0 & 0 & 0 & 0 & 0 & 0 & 0 \\
\hline Tot. number selected & 23 & 17 & 20 & 13 & 23 & 21 & 14 & 87 \\
\hline
\end{tabular}

ficient and not wide enough to invalidate the analysis. We believe this statement is accurate for several reasons. First, the analysis produces the following significant results:

1. The countries with the highest significance in terms of the represented factors are the most developed (e.g., United States, United Kingdom, Japan, Germany and France);

2. The most influential factors are related to business and macroeconomics, consistent with those affirmed by the APT (Burmeister, Wall 1986);

3. The key equity indices are the global market indices;

4. The main commodities (oil and gold) appear not relevant, but they are included in the equity indices category;

5. The main market indices are key factors, as affirmed by the CAPM and the threeand four-factor theories; and

6. The other most significant factors, with a few rare exceptions, are those that are 
linked to oil, gold, production, level of consumer confidence, volume of exports and imports of main economies, interest rates, GDP levels, money flows, and salary and workforce levels. It is interesting to note that investors typically view these factors as "market movers".

Table 3 presents a summary of the top fifteen most important factors in period $\mathrm{H}$ (2000-2007). We consider this period as these are currently the most important factors and are expected to be relevant for the foreseeable future.

From Table 3, we can deduce that the business and macroeconomics factors are the key factors that heavily affect asset returns. Apart from the European market index, all other key factors are macroeconomic: currency rate, balance of payments, inflation rate, trend of real GDP, imports and exports, and unemployment rate are expected aspects that can be found in the list. It is also interesting to note that in the 2000-2007 period, a major role is played by specific factors such as banks' housing loans and U.S. securities other than U.S. Treasury securities. These represent frequently mentioned "keywords" in the critical period before the recent financial crisis. Also from Table 3, the predominance of the U.S. at a global level also emerges, since the majority of the key factors relate to North America, which still dominates in determining the performance of international financial markets. Overall, Table 3 presents a broad collection of factors that affect asset returns, and whose weight varies according to the sub-period investigated.

Table 3. First 15 most important factors identified by the analysis in period H (2000-2007)

\begin{tabular}{|c|c|c|c|c|c|}
\hline Factor name & Area & Type & Intertemporal $^{3}$ & $\begin{array}{l}\text { Absolute } \\
\text { frequency }\end{array}$ & $\begin{array}{c}\text { No. of } \\
\text { companies } \\
(\mathrm{H})^{2}\end{array}$ \\
\hline$\$$ currency rate & $\begin{array}{c}\text { Asia } \\
\text { (Japan) }\end{array}$ & $\begin{array}{l}\text { Macroec./ } \\
\text { business }\end{array}$ & Yes & 3385 & 2584 \\
\hline Balance of payments & United States & $\begin{array}{l}\text { Macroec./ } \\
\text { business }\end{array}$ & No & - & 2569 \\
\hline Banks' housing loans & Germany & $\begin{array}{l}\text { Macroec./ } \\
\text { business }\end{array}$ & Yes & 3157 & 2448 \\
\hline $\begin{array}{l}\text { European market } \\
\text { index }\end{array}$ & Europe & Equity indices & Yes & 4321 & 2648 \\
\hline $\begin{array}{l}\text { Imports from western } \\
\text { hemisphere }\end{array}$ & I & $\begin{array}{l}\text { Macroec./ } \\
\text { business }\end{array}$ & Yes & 2724 & 2154 \\
\hline Inflation rate & Europe & $\begin{array}{l}\text { Macroec./ } \\
\text { business }\end{array}$ & Yes & 3870 & 2255 \\
\hline $\begin{array}{l}\text { Main refinancing } \\
\text { operation (ECB) }\end{array}$ & Europe & $\begin{array}{l}\text { Macroec./ } \\
\text { business }\end{array}$ & No & - & 2428 \\
\hline $\begin{array}{l}\text { Private fixed } \\
\text { investment }\end{array}$ & United States & $\begin{array}{l}\text { Macroec./ } \\
\text { business }\end{array}$ & No & - & 2905 \\
\hline $\begin{array}{l}\text { Public corp. gross } \\
\text { disposable income }\end{array}$ & $\begin{array}{l}\text { United } \\
\text { Kingdom }\end{array}$ & $\begin{array}{l}\text { Macroec./ } \\
\text { business }\end{array}$ & No & - & 2174 \\
\hline
\end{tabular}


End of Table 3

\begin{tabular}{|c|c|c|c|c|c|}
\hline Factor name & Area & Type & Intertemporal $^{3}$ & $\begin{array}{l}\text { Absolute } \\
\text { frequency }\end{array}$ & $\begin{array}{c}\text { No. of } \\
\text { companies } \\
(\mathrm{H})^{2}\end{array}$ \\
\hline Real GDP & United States & $\begin{array}{l}\text { Macroec./ } \\
\text { business }\end{array}$ & Yes & 3726 & 2982 \\
\hline Unit labor costs & $\begin{array}{l}\text { OECD } \\
\text { Total }\end{array}$ & $\begin{array}{l}\text { Macroec./ } \\
\text { business }\end{array}$ & No & - & 2782 \\
\hline $\begin{array}{l}\text { US securities but } \\
\text { treasury securities }\end{array}$ & United States & $\begin{array}{l}\text { Macroec./ } \\
\text { business }\end{array}$ & No & - & 2382 \\
\hline US unemployment & United States & $\begin{array}{l}\text { Macroec./ } \\
\text { business }\end{array}$ & No & - & 2428 \\
\hline Volume of exports & $\begin{array}{c}\text { Asia \& } \\
\text { Middle East }\end{array}$ & $\begin{array}{l}\text { Macroec./ } \\
\text { business }\end{array}$ & No & - & 2569 \\
\hline $\begin{array}{l}\text { Volume of exports - } \\
\text { petroleum }\end{array}$ & Middle East & $\begin{array}{l}\text { Macroec./ } \\
\text { business }\end{array}$ & No & - & 2648 \\
\hline
\end{tabular}

Notes: ${ }^{1}$ Frequency calculated considering all the periods A-H.

${ }^{2}$ Number of companies affected by the factor in period $\mathrm{H}$.

${ }^{3}$ Presence of the factor in other periods.

${ }^{4}$ European market index is a factor built on purpose by authors, by weighting the returns of single European markets by their market capitalization.

As suggested in the hypotheses, we can observe factors that influence returns, both positively (positive betas) and negatively (negative betas). The results make it possible to distinguish the years when negative returns were recorded. Our hypotheses were designed to help us identify the factors that affect all companies positively or negatively, as well as those that positively or negatively affect only some companies.

Surprisingly, we have not identified factors that affect all companies positively or negatively. This is important for financial analysts looking for diversification, which they could achieve by building a portfolio with factors that are negatively correlated. Indeed, we write that:

$$
\sigma_{G}=\sqrt{\sum_{i=1}^{n} \sum_{j=1}^{n} \beta_{i} \beta_{j} \rho\left(f_{i} f_{j}\right) \sigma_{f i} \sigma_{f j}} .
$$

Thus, ceteris paribus, risk is minimised when the correlation index between the factors is low (see Appendix for detailed formula).

Two relevant aspects are particularly significant in Table 4. The first aspect is the identification of different key factors in different periods. This is a confirmation of our hypothesis HP 5 that the strength of a factor changes over time; otherwise, we would have always found the same factors for all of the periods, as hypothesised by the CAPM, three- and four-factor models and the APT. The second important aspect is the presence of "inter-temporal" factors, whose importance changes more slowly than others. 
Table 5 reports the common factors identified by the algorithm in each period. It appears that the average persistence of an "inter-temporal" factor is between 10 and 20 years. Furthermore, in some cases the inter-temporal factor does not disappear, but is again included in a new index.

Table 4. Factor analysis. Resumptive explanatory results

\begin{tabular}{lcccc}
\hline & $\begin{array}{c}\text { Sum of the no. } \\
\text { of factors }\end{array}$ & $\begin{array}{c}\text { Total no. } \\
\text { of factors }\end{array}$ & $\begin{array}{c}\text { Common } \\
\text { factors }^{3}\end{array}$ & $\begin{array}{c}\text { Common } \\
\text { factors (\%) }\end{array}$ \\
\hline Period A-H & 218 & 188 & 30 & $16 \%$ \\
\hline
\end{tabular}

Note: ${ }^{1}$ Considering singular periods.

${ }^{2}$ Considering a unique period.

${ }^{3}$ Calculated as a difference.

Table 5. "Matrix of common factors"

\begin{tabular}{cccccccccc}
\hline & $\mathrm{A}$ & $\mathrm{B}$ & $\mathrm{C}$ & $\mathrm{D}$ & $\mathrm{E}$ & $\mathrm{F}$ & $\mathrm{G}$ & $\mathrm{H}$ & Total \\
\hline $\mathrm{A}$ & - & 1 & 0 & 0 & 0 & 0 & 1 & 0 & 2 \\
\hline $\mathrm{B}$ & - & - & 3 & 2 & 0 & 1 & 0 & 0 & 6 \\
\hline $\mathrm{C}$ & - & - & - & 1 & 1 & 1 & 0 & 1 & 4 \\
\hline $\mathrm{D}$ & - & - & - & - & 1 & 1 & 1 & 0 & 3 \\
\hline $\mathrm{E}$ & - & - & - & - & - & 4 & 0 & 1 & 5 \\
\hline $\mathrm{F}$ & - & - & - & - & - & - & 2 & 4 & 6 \\
\hline G & - & - & - & - & - & - & - & 4 & 4 \\
\hline & & & & & & & & & \\
\hline
\end{tabular}

Table 6 reports the number of factors selected that are related to the companies considered in each period. We have calculated a ratio that we have named "factors exposure" as the number of companies divided by the total number of factors selected for each period. Thus, given an equal number of companies, a lower factors exposure would imply a higher factor diversification, that is, more factors explain the return. At first glance, the number of factors increases with the length of time considered; for period $\mathrm{H}$ (eight years), we need more than six times the factors of period $\mathrm{G}$ (five years). However, in period $\mathrm{H}$ the value for the factors exposure is the third lowest of all the periods considered. This result is significant and quite impressive, since it indicates that only 87 factors explain the returns of 4,500 companies in the fifteen European countries over the eight years analysed. 
Table 6. Exposure of the periods to factors

\begin{tabular}{cccc}
\hline Period & $\begin{array}{c}\text { No. of companies } \\
\text { analyzed (A) }\end{array}$ & $\begin{array}{c}\text { Total no. of factors } \\
\text { selected (B) }\end{array}$ & $\begin{array}{c}\text { Factors exposure } \\
\text { (B/A) }\end{array}$ \\
\hline A & 154 & 23 & 0.15 \\
\hline B & 291 & 17 & 0.06 \\
\hline C & 569 & 20 & 0.04 \\
\hline D & 428 & 13 & 0.03 \\
\hline E & 805 & 23 & 0.03 \\
\hline F & 1,482 & 21 & 0.01 \\
\hline G & 1,648 & 14 & 0.01 \\
\hline H & 4,540 & 87 & 0.02 \\
\hline
\end{tabular}

Note: where factors exposure can be expressed as the ratio between the total number of factors selected and the number of companies analyzed.

Furthermore, the trend of the factors exposure is particularly interesting and also suggests something else. While we observe a stronger participation in the stock market, with an increasing number of listed companies and an increasing number of investors involved, the number of factors necessary to exhaustively explain the asset returns decreases. This is a direct consequence of the growing level of diversification between factors, due to the increased efficiency of financial markets over time.

\section{Conclusions}

In this paper we suggest that multiple factors can affect the relationship between risk and return. The empirical analyses support our research hypotheses. As suggested by HP 1, a plethora of factors can affect returns to a different extent. It is interesting to observe that business and macroeconomic factors, more than financial factors, are those that heavily bear on asset returns. As suggested by HP 2, the analysis supports that, since not all firms are always sensitive to the same factors, the possibility exists to further decrease risk in proportion to return through a factor-based risk optimisation process. Accordingly, when investors are not optimally diversified, the presence of potentially diversifiable factors could play a leading role in a renewed definition of the investment strategy. Considering that not all factors are traded in a market, an investor could investigate whether or not optimal diversification is possible, and/or whether or not arbitrage opportunities on single factors can be identified. As suggested by HP 3, the findings also support that diversification is directly related to the presence of negatively correlated factors; the overall risk of an asset varies with the level of risk of the considered factors; and investors do not appear to be perfectly diversified. In addition, an important finding from our analysis of a period covering more than 50 years is that it is not possible to identify "good" or "bad" factors that affect asset returns in solely a positive or 
negative manner; however, the same factor can positively affect some companies and negatively others. Furthermore, as suggested by HP 4, the influence of different factors is different and, as suggested by HP 5, their magnitude is also changeable over time (see Tables 4-6). There is a strict relationship between our model and the CAPM, because the CAPM considers the market as a unique explanatory variable of asset return, while we consider the market as "one of the possible portfolios" that can be explained by a wider cluster of factors. However, as the market is the largest portfolio that can be constructed, the market itself is the place where the maximum diversification level of all factors is achieved. Thus, the factors that explain market return are solely those that also explain the return of any other portfolio.

\section{Acknowledgments}

The authors thank the reviewers for their valuable comments. Also, an acknowledgement to Maurizio Dallocchio for his support in the work.

\section{References}

Bergman, Y. Z. 1985. Time preference and Capital Asset Pricing Model, Journal of Financial Economics 1(2): 145-159. http://dx.doi.org/10.1016/0304-405X(85)90047-9

Burmeister, E.; Wall, K. D. 1986. The Arbitrage Pricing Theory and macroeconomic factor measures, The Financial Review 21(2): 1-20. http://dx.doi.org/10.1111/j.1540-6288.1986.tb01103.x Carhart, M. M. 1997. On persistence in mutual fund performance, Journal of Finance 52(1): 57-82. http://dx.doi.org/10.1111/j.1540-6261.1997.tb03808.x

Cequity. 2009. Enhancing analytical modeling for large data sets with variable reduction, Whitepapers (January).

Elton, E. J.; Gruber, M. J.; Mei, J. 1994. Cost of capital using Arbitrage Pricing Theory: a case study of nine New York utilities, Financial Markets, Institutions and Instruments 3(3): 46-73.

Fama, E. F.; MacBeth, J. D. 1973. Risk, return, and equilibrium: empirical tests, Journal of Political Economy 81(3): 607-636. http://dx.doi.org/10.1086/260061

Fama, E. F.; French, K. R. 1992. The cross-section of expected stock returns, Journal of Finance 47(2): 427-465. http://dx.doi.org/10.1111/j.1540-6261.1992.tb04398.x

Fama, E. F.; French, K. R. 2004. The Capital Asset Pricing Model: theory and evidence, Journal of Economic Perspective 18(3): 25-46. http://dx.doi.org/10.1257/0895330042162430

Jensen, M. C. 1972. Capital markets: theory and evidence, Bell Journal of Economics and Management Science 3(2): 357-398. http://dx.doi.org/10.2307/3003029

Kostakis, A. 2009. Performance measures and incentives: loading negative coskewness to outperform the CAPM, European Journal of Finance 15(5-6): 463-486.

http://dx.doi.org/10.1080/13518470902872327

Lee, C. F.; Tsai, C. M;. Lee, A. C. 2009. A dynamic CAPM with supply effect: theory and empirical results, The Quarterly Review of Economics and Finance 29(3): 811-828.

http://dx.doi.org/10.1016/j.qref.2009.01.001

Levy, H. 1983. The Capital Asset Pricing Model: theory and empiricism, Economic Journal 39(369): 145-165. http://dx.doi.org/10.2307/2232170

Levy, H. 2010. The CAPM is alive and well: a review and synthesis, European Financial Management 16(1): 43-71. http://dx.doi.org/10.1111/j.1468-036X.2009.00530.x 
Levy, H.; De Giorgi, E. G.; Hens, T. 2012. Two paradigms and Nobel Prizes in economics: a contradiction or coexistence?, European Financial Management 18(2): 163-182.

http://dx.doi.org/10.1111/j.1468-036X.2011.00617.x

Li, B.; Yin, X. 2011. Information and capital asset pricing, European Journal of Finance 17(7): 505-523. http://dx.doi.org/10.1080/1351847X.2010.495476

Magni, C. A. 2009. Correct or incorrect application of CAPM? Correct or incorrect decisions with CAPM?, European Journal of Operational Research 192(2): 549-560.

http://dx.doi.org/10.1016/j.ejor.2007.09.027

Markowitz, H. M. 2005. Market efficiency: a theoretical distinction and so what?, Financial Analysts Journal 61(5): 17-30. http://dx.doi.org/10.2469/faj.v61.n5.2752

Roll, R. 1977. A critique of the Asset Pricing Theory's test, Journal of Financial Economics 4(2): 129-176. http://dx.doi.org/10.1016/0304-405X(77)90009-5

Roll, R.; Ross, S. A. 1980. An empirical investigation of the Arbitrage Pricing Theory, Journal of Finance 35(5): 1073-1103. http://dx.doi.org/10.1111/j.1540-6261.1980.tb02197.x

Ross, S. 1976. The arbitrage theory of capital asset pricing, Journal of Economic Theory 13(3): 341-360. http://dx.doi.org/10.1016/0022-0531(76)90046-6

Sharpe, W. F. 1964. Capital asset prices: a theory of market equilibrium under conditions of risk, Journal of Finance 19(2): 425-442.

Siegel, L. B. 2010. Black swan or black Turkey? The state of economic knowledge and the crash of 2007-2009, Financial Analysts Journal 66(4): 6-10. http://dx.doi.org/10.2469/faj.v66.n4.4

Teti, E.; Dell'Acqua, A.; Zocchi, F. 2012. UN PRI and private equity returns. Empirical evidence from the US market, Investment Management and Financial Innovations 9(3): 60-67.

\section{APPENDIX}

If we suppose that the return of the portfolio $G$ during a period $T$ depends on $n$ factors, we can write that:

$$
\bar{r}_{G}=\bar{\alpha}+\frac{1}{T} \sum_{i=1}^{n} \sum_{t=1}^{T} \beta_{i} f_{i, t}
$$

where $\beta_{i}$ is the sensitivity of the portfolio return to factor $i, f_{i, t}$ is the change of factor $i$ between two periods, measured as:

$$
f_{i, t}=\frac{f_{i, t}-f_{i, t-1}}{f_{i, t-1}}
$$

and thus $\bar{\alpha}$ is the average return calculated as $\left[\frac{P_{1}+D I V_{1}-P_{0}}{P_{0}}\right]$ of the portfolio $G$ when the sensitivity to any factor is zero. We can write also that:

$$
\bar{r}_{G}-\bar{\alpha}=\frac{1}{T} \sum_{i=1}^{n} \sum_{t=1}^{T} \beta_{i} f_{i, t} .
$$


If we define the risk of the portfolio $G$ as:

$$
\sigma_{G}^{2}=\frac{1}{T} \sum_{t=1}^{T} r_{G, t}^{2}-T_{G}^{2},
$$

where $\bar{r}_{G}$ is the average return over the period $T$. Simplifying:

$$
\sigma_{G}^{2}=V A R(\alpha)+\sum_{i=1}^{n} \sum_{j=1}^{n} \beta_{i} \beta_{j} C O V\left(f_{i} f_{j}\right) .
$$

Because $\alpha$ is the return of the portfolio when the sensitivity to any factors is zero, we can write that: $\operatorname{VAR}(\alpha)=0$. Thus, the standard deviation is:

$$
\sigma_{G}=\sqrt{\sum_{i=1}^{n} \sum_{j=1}^{n} \beta_{i} \beta_{j} \operatorname{COV}\left(f_{i} f_{j}\right)}
$$

and the Sharpe Ratio for $G$ is:

$$
S_{G}=\frac{\frac{1}{T} \sum_{i=1}^{n} \sum_{t=1}^{T} \beta_{i} f_{i, t}}{\sigma_{G}} .
$$

If we calculate the Relative Importance Index for the generic factor $p$ part of the portfolio $G$, we have:

$$
R I I_{p}=\frac{\beta_{p} * \frac{1}{T} \sum_{t=1}^{T} f_{t, p}}{\sigma_{G}} .
$$

Mauro ANDRIOTTO is a researcher at the Department of Finance at Bocconi University and researcher for the Research Centre on Sustainability and Value (CReSV) at Bocconi University. His interests cover themes of corporate finance, asset pricing and asset allocation, risk analysis, financial engineering.

Emanuele TETI is Adjunct Professor of financial management at Bocconi University, Milan, and professor at SDA Bocconi School of Management. He is senior researcher for the Research Centre on Sustainability and Value (CReSV) at Bocconi University. He has published different papers in peerreviewed Journals on a wide range of subjects concerning financial management, cultural economics, entrepreneurship, market functioning, sustainable development. 